\title{
Small Farm Households' Vulnerabilities in South Cotabato, Philippines
}

\author{
Rosalina Palanca-Tan'1, Leonora F. Gio² \\ ${ }^{1}$ Department of Economics, Ateneo de Manila University, Quezon City, Philippines \\ ${ }^{2}$ College of Business Administration, Notre Dame of Marbel University, City of Koronadal, Philippines \\ Email:rtan@ateneo.edu, leonoragio@yahoo.com
}

How to cite this paper: Palanca-Tan, R. and Gio, L.F. (2021) Small Farm Households' Vulnerabilities in South Cotabato, Philippines. Agricultural Sciences, 12, 247-258. https://doi.org/10.4236/as.2021.123016

Received: February 7, 2021

Accepted: March 22, 2021

Published: March 25, 2021

Copyright $\odot 2021$ by author(s) and Scientific Research Publishing Inc. This work is licensed under the Creative Commons Attribution International License (CC BY 4.0).

http://creativecommons.org/licenses/by/4.0/

\begin{abstract}
Low-productivity subsistence agriculture still prevails in many areas in the Philippines such as in the Municipality of Lake Sebu in the Province of South Cotabato in Mindanao. This study employs primary data collection methods, namely key informant interview (KII), focus group discussion (FGD) and a household survey to assess the conditions and problems constraining farming households in Lake Sebu. The study finds that constraints on sourcing and financing of farm inputs and on marketing of produce have perpetuated the dominating role of middlemen in agricultural financing and marketing that result in high input prices and low farm-gate output prices, and hence minimal net income for the farmers. The paper concludes with specific policy and program recommendations to achieve maximum and sustainable farming benefits, namely, an expansive farm-to-market infrastructure program, an institution and business support intervention program to link farmers and markets, conditional cash farming subsidies in lieu of direct provision of farm inputs, and crop diversification promotion and support programs.
\end{abstract}

\section{Keywords}

Agriculture, Poverty, Agricultural Policy, Philippines

\section{Introduction}

More than any other industry, agriculture occupies a key spot in poverty alleviation, income equality and food security. Agriculture is the source of livelihood of more than 2.2 billion people or half of the population in Asia, and hence, the sector is crucial in improving the prospects of achieving the first Millennium Development Goal target in the region (Imai et al., 2011) [1]. The World Bank (2020) [2] claims that "agricultural development is one of the most powerful 
tools to end extreme poverty, boost shared prosperity and feed a projected 9.7 billion people by 2050 " and that growth in the agriculture sector is two to four times more effective in raising incomes among the poorest. However, the agricultural sector in many developing countries, such as the Philippines, has trailed behind the entire economy. And this raises questions on how the agricultural sector can fulfill its anticipated poverty alleviation impact.

In the Philippines, the growth of the agricultural sector has remained weak, with its share in the country's gross domestic product (GDP) on a continuous decline. Over the years 2008-2018, while the entire Philippine economy remained on a sustained growth trajectory, with its GDP growing at an annual average rate of 5.8\%, the agriculture sector (excluding forestry) grew at a minimal rate of $1.1 \%$ and the sector's share in GDP continuously slid down from 12.5\% in 2009 to $8.0 \%$ in 2018. Part of the reduction in agriculture's share in GDP is attributed to structural transformation as Philippine economic growth is largely powered by industry and services (Brown et al., 2018 [3]). Nonetheless, the World Bank report points to the persistently low productivity as the more important and alarming factor behind the dwindling share of agriculture. The World Bank notes that the growth in total factor productivity in Philippine agriculture of $32 \%$ over the past two decades is much slower compared to Vietnam's $73 \%$, Thailand's $67 \%$, and Indonesia's 50\%. Philippine agricultural productivity has remained low as landholdings have become more fragmented and mechanization has not proceeded as needed. The government has continued its traditional policy focus on rice and despite significant resources allocated to rice farming, Philippine rice farm yields are still far below the average for Southeast Asian countries. Further, Philippine agriculture has failed to diversify, with the share of high-value crops increasing only marginally from $19.6 \%$ in 2000 to $20.6 \%$ in 2018, and to $22.9 \%$ in 2019, even with the High-Value Crops Development Act of 1995 (World Bank, 2020 [2]). A closer look at the issues, particularly on the local level, may give a deeper understanding of the problems, and of what can be done to address them.

This paper looks into crop farming in Lake Sebu, a predominantly agricultural municipality in the Province of South Cotabato in Mindanao, Philippines. The Municipality of Lake Sebu is endowed with abundant land resources and has climatic conditions that are conducive for farming. About a third of its land area is used for the production of corn, rice, fruits, vegetable and other crops; and up to the present, majority of the households are dependent on agriculture as the primary source of livelihood, despite the recent emergence of other more lucrative income sources such as tourism and aquaculture. Thus, in addressing poverty and income inequality concerns in the area, agriculture remains to be the critical sector.

This study employs primary data collection methods, namely key informant interview (KII), focus group discussion (FGD) and a household survey to assess the conditions and problems constraining farming households in the Municipal- 
ity so as to identify appropriate public policies and programs to achieve maximum and sustainable farming benefits for the residents of Lake Sebu.

Findings from the study reveal that despite very low profitability from corn, Lake Sebu farmers are concentrated in corn farming with about $53 \%$ of total agricultural area devoted to this crop. Other crops, specifically coconut, banana, abaca, rubber, beans and other vegetables entail much lower costs and a much higher earning potential for farmers, but only few Lake Sebu farmers plant them on a commercial scale. FGDs with farmers reveal that financing and marketing constraints prevent the farmers from shifting to more profitable crops. Lake Sebu farmers are heavily dependent on non-resident capitalists that prefer to finance corn production at a high interest rate and buy corn yields at a low price. Unless this one-sided set-up is eradicated, agriculture's role in poverty alleviation in the Municipality cannot be realized. The paper concludes with specific recommendations on the forms and designs of government support programs to overcome farming constraints in Lake Sebu.

\section{Overview of Lake Sebu Agriculture}

The Municipality of Lake Sebu in southern Philippines (Figure 1) lies below the typhoon belt with good climatic conditions conducive to farming. It also has fertile soil on wide-ranging land elevations that are suitable for growing a variety of crops.

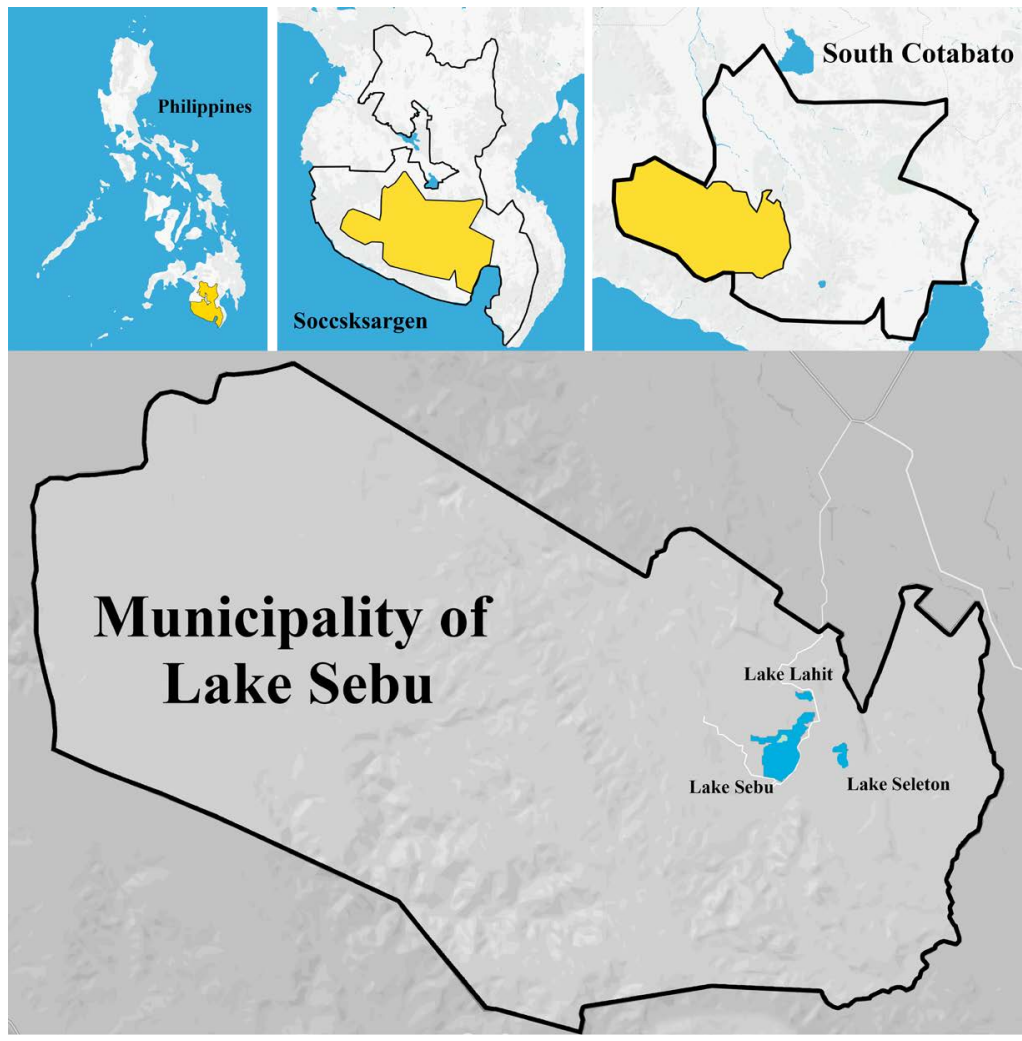

Figure 1. The study site (municipality of Lake Sebu). 
Almost a third (30\%) of the Municipality's total land area is agricultural. More than half of this agricultural land (53\%) is planted to corn while only $8 \%$ is planted to rice (Lake Sebu Municipal Planning and Development Office (LSMPDO), 2015 [4]). The remaining agricultural land in the Municipality is planted to other crops such as coffee (299.42 ha or 1.12\%), banana (288.65 ha or $1.08 \%$ ), rubber (200.27 ha or $0.75 \%$ ), durian ( 155.81 ha or $0.58 \%)$, tomato (115.25 ha or $0.43 \%)$, and lanzones (109.77 ha or $0.41 \%)$, vegetable (150 ha or $0.56 \%)$, cacao ( $37 \mathrm{ha})$, and cassava (30 ha). The predominance of corn over rice farming in Lake Sebu is partly due to its topography. Lake Sebu is estimated to be 700 meters above sea level with the Barangay Poblacion as the point of reference. Its terrain is largely rugged with the mountain ranges of Daguma and Talihik and Mt. Talili (with an elevation of $1410 \mathrm{~m}$ ) along the Municipality's eastern portion, Mt. Busa (with an elevation of $2064 \mathrm{~m}$ ) in its southeastern portion, and Pitot Kalabao Peak (with an elevation of $1600 \mathrm{~m}$ ) along its central portion (LSMPDO, 2016 [5]). Productivity of rain-fed upland rice farming is typically low, compared to irrigated lowland rice farming. Thus, Lake Sebu farmers, produce rice mainly for family consumption.

As Lake Sebu comprises the few hills and mountains of the generally flat province of South Cotabato, its corn production area is the largest in the province, accounting for about $27.45 \%$ of the province total corn production area, while its rice production area is just the seventh largest (out of 11 municipalities) accounting for barely $5.83 \%$ of the province rice production area. For high-value commercial crops, Lake Sebu ranks second in term of farming area for coffee (388 ha or $19.91 \%$ of coffee farm land in South Cotabato) and rubber (267 ha, $24.84 \%$ ), and ranks third for vegetables (150 ha, 12.10\%) and cacao (27 ha, 8.03\%) (Office of the Municipal Agriculturist, 2019 [6]).

In terms of production, Lake Sebu as well as South Cotabato's corn and rice harvests remained flat over the last five years 2015-2019 (Table 1). Lake Sebu's average annual corn production of 139 thousand metric tons accounted for $28.19 \%$ of South Cotabato's production, while its average annual rice production of 18.6 thousand metric tons was just a mere $4.39 \%$ of the province's rice output. It appears that both corn and rice farms in Lake Sebu performed slightly better than the whole province in the past five years.

\section{Farming Households' Income and Welfare}

This paper is part of a bigger research project that aims to estimate the total economic value derived from the natural and cultural resources in Lake Sebu. One component of the research is a household livelihood survey that asked detailed sector-specific questions on income sources of all household members. The respondent was asked which among the following six categories of income sources the household depends on: 1) fishing; 2) tourism; 3) crop farming; 4) livestock and poultry; 5) government/public service; and 6) others. After identifying one income source, a series of questions that would allow calculation of net 
Table 1. Corn and rice production in Lake Sebu and South Cotabato, 2015-2019.

\begin{tabular}{ccccccc}
\hline & \multicolumn{2}{c}{$\begin{array}{c}\text { Lake Sebu } \\
\text { (metric tons) }\end{array}$} & \multicolumn{2}{c}{$\begin{array}{c}\text { South Cotabato } \\
\text { (metric tons) }\end{array}$} & \multicolumn{2}{c}{$\begin{array}{c}\text { Share of Lake Sebu in } \\
\text { South Cotabato (\%) }\end{array}$} \\
\cline { 2 - 7 } & Corn & Rice & Corn & Corn & Rice & Corn \\
\hline 2015 & 139,273 & 17,250 & 496,895 & 441,903 & $28.03 \%$ & $3.90 \%$ \\
2016 & 120,102 & 19,441 & 463,887 & 399,540 & $25.89 \%$ & $4.87 \%$ \\
2017 & 167,577 & 15,700 & 556,220 & $439,987.8$ & $30.13 \%$ & $3.57 \%$ \\
2018 & 144,274 & 21,344 & 505,056 & $410,988.4$ & $28.57 \%$ & $5.19 \%$ \\
2019 & 123,821 & 18,860 & 436,759 & 426,694 & $28.35 \%$ & $4.42 \%$ \\
Average & 139,010 & 18,519 & 491,763 & 423,823 & $28.19 \%$ & $4.39 \%$ \\
Average annual & $-0.58 \%$ & $4.44 \%$ & $-2.36 \%$ & $-0.56 \%$ & & \\
growth rate (\%) & & & & & & \\
\hline
\end{tabular}

Source of data: Department of Agriculture, Office of South Cotabato, 2019.

income or revenues from each income source were asked. In the case of farming, questions on the types of crops, frequency, volume and value of harvests, and costs of farming inputs were asked. Revenues from agriculture are computed such that non-cash revenues (e.g.: food for home consumption and for give-aways to relatives and friends) are also included (i.e.: revenues are based on harvest/production value, and not on sales value). Apart from income, questions on consumption and subjected happiness were asked to assess the over-all welfare conditions of the households. For subjective happiness, the actual question posed in the survey instrument followed the 10-point numerical rating scale of Cantril (1965) [7]: "How happy or contented are you with your current living conditions. Please answer using a scale of $0-10$ where 0 is very unhappy and discontented and 10 is perfectly happy and contented."

A total sample of 489 respondent households was generated through in-person interview by experienced enumerators of the Research Center of Notre Dame of Marbel University during the month of February 2019. All 19 barangays of Lake Sebu except Ned were included in the sampling frame. Ned is quite distant and isolated from the rest of the municipality. Farming households in Ned are very far from each other, which makes the survey method very difficult to implement in the barangay. Hence, an FGD with farmers in Barangay Ned was conducted ${ }^{1}$.

Majority of the household-respondents (287 or $58.69 \%$ of total household respondents) were engaged in crop farming activities, indicating that the means of livelihood in the Municipality is still predominantly crop farming despite the growing tourism and fishing (particularly aquaculture) industries that provide livelihood to only 94 or $19.22 \%$ and 50 or $10.22 \%$, respectively, of surveyed

${ }^{1}$ Field research constraints in Barangay Ned include distance and road constraints, very poor telecommunication signals, as well as peace and order condition. 
households. About a quarter (212 or 73.87\%) of these crop-farming households indicated that farming is the primary income source of the household. Farm production data such as crop type, farm area, harvest and inputs were obtained from 204 farming household respondents. Those who are mere farm workers were not asked farm production details.

Survey results confirm the dominance of corn over rice in Lake Sebu agriculture. One hundred fifty or $73.53 \%$ of the surveyed households are into corn farming, while only 20 or $9.80 \%$ are into rice farming. A number of surveyed farming households are planting tomatoes (26 households or $12.75 \%$ of surveyed farming households), abaca (16 or $7.84 \%$ ), banana (16 or $7.84 \%$ ), and coconut (13 or $6.37 \%)$. Other crops planted by surveyed farming households are bell pepper (5 households), rubber (4), squash (4), Baguio beans (4), durian (3), eggplant (3), string beans (2), radish (2), and taro, okra, coffee, green of finger chili, chili pepper, pineapple and Chinese cabbage ( 1 household each in the sample). According to the Municipal Agriculturist of Lake Sebu, the farming households are mostly the indigenous T'boli who prefer and are more used to planting corn, their traditional crop, and are reluctant to shift to other agricultural crops (e.g.: permanent crops such as fruit trees) being promoted by the government.

Table 2 summarizes findings from the survey on revenues, costs and net income of farming households, by crop type. Annual gross farming income or revenues are calculated by multiplying production volume per harvest/cropping season by the number of harvest/cropping seasons per year and then, by the price per unit of harvest. Price per unit of harvest was asked directly in the survey, and/or derived from revenue figures and production volume indicated by surveyed households. Costs include cash costs, non-cash costs and imputed costs for the following items: labor (hired labor and family labor and their on-farm meal costs), materials (seeds, fertilizer, pesticides), hauling and trucking (including gasoline), drying, lease and rentals, and irrigation.

Table 2. Farm area, gross returns, costs, and net returns per year, by crop.

\begin{tabular}{|c|c|c|c|c|c|c|c|}
\hline \multirow{2}{*}{ Crop } & \multirow{2}{*}{$\begin{array}{l}\text { Number of } \\
\text { households }\end{array}$} & \multicolumn{4}{|c|}{ Per household } & \multirow{2}{*}{$\begin{array}{c}\text { Net returns } \\
\text { per ha }\end{array}$} & \multirow{2}{*}{$\begin{array}{l}\text { Net returns to } \\
\text { costs ratio }\end{array}$} \\
\hline & & Farm area (ha) & $\begin{array}{c}\text { Gross returns } \\
\text { (PHP) }\end{array}$ & Costs (PHP) & $\begin{array}{l}\text { Net returns } \\
\quad(\mathrm{PHP})\end{array}$ & & \\
\hline Corn & 150 & 1.71 & $65,655.54$ & $51,281.31$ & $14,374.24$ & $8,405.99$ & 0.28 \\
\hline Rice & 20 & 1.19 & $89,349.50$ & $46,803.31$ & $42,546.19$ & $35,753.10$ & 0.91 \\
\hline Tomatoes & 26 & 0.70 & $58,365.00$ & $39,370.58$ & $18,994.42$ & $27,134.89$ & 0.48 \\
\hline Abaca & 16 & 1.45 & $45,445.63$ & $20,127.97$ & $25,317.66$ & $17,460.46$ & 1.26 \\
\hline Banana & 16 & 0.78 & $21,621.88$ & 8265.31 & $13,356.56$ & $17,123.79$ & 1.62 \\
\hline Coconut & 13 & 1.47 & $14,135.00$ & 4758.08 & 9376.92 & 6378.86 & 1.97 \\
\hline Others & 34 & 0.72 & $18,351.18$ & 7720.62 & $10,630.56$ & $14,764.67$ & 1.38 \\
\hline
\end{tabular}


Based on survey results, corn farming appears to be the least profitable. On the average, a corn farming household cultivates an average of $1.71 \mathrm{ha}$, generates an annual gross revenues or gross value of production of PHP65,656. However, substantial farming costs of PHP51,281 which wipes out $78.11 \%$ of revenues leaves very little (only an annual net income of PHP14,374.24) to the household. Net returns per hectare of corn farm is very low at P8,405.99, and the resulting net returns to cost ratio from corn farming turns out to be the lowest among all crops farmed in the Municipality. On the other hand, rice farming households in Lake Sebu till just an average of 1.19 ha but generate annual revenues of PHP89,349, the highest among all crops. Production costs of PHP46,803 is even lower than corn's, thereby generating net income to the rice farming household that is about thrice the amount realized by the average corn farming household. Net revenues per hectare from rice is more than four times that from corn and the net revenue to cost ratio is about three times that of corn farming. Net returns and profitability from other crops likewise appear to be much better than corn. With generally less land devoted to cultivation of other crops and much less costs involved, annual net incomes realized by households from farming of other crops are comparable, if not higher than corn. All the other crops-abaca, banana, coconut and other non-traditional crops have remarkably much lower costs, yielding net revenues to cost ratio of more than one. With the exception of coconut, net returns per hectare from all other crops are greater than that from corn. Survey data indicate that despite relatively high gross revenues from corn farming, substantial costs diminish net returns/income.

Data from the Philippine Statistics Office (PSA) reflect an improvement in the profit to cost ratio of corn farming in the Philippines from 0.25 in 2010, to 0.63 in 2015, and to 0.78 in 2018 (PSA, 2010 [8], 2015 [9], 2018 [10]). Survey results from this study suggest that corn farming profitability in Lake Sebu has remained on the 2010 level of the Philippines.

Welfare indicators, such as aggregate household income, poverty incidence, food consumption vulnerability and self-reported happiness are presented in Table 3. Welfare measures for households whose main income source is farming as well as for households that are dependent on other livelihood sources such as tourism, tilapia aquaculture and others (public/government service, transportation, construction, merchandising/retail trading, food and clothing/apparel) are provided so as to show the relative socio-economic conditions of farming households in the Municipality. Table 3 reveals that households who are mainly dependent on agriculture (crop farming) are worse-off than other households in the Municipality. On the average, annual income of other households is about 30-100\% larger that income of farming households. Poverty incidence and hunger incidence are substantially higher among farming households than other households. More than three-fourths of farming households in Lake Sebu are below the poverty line. Majority of the farming households are experiencing hunger. Further, the average happiness score is lowest for farming households. 
Table 3. Household welfare indicators, by main source of income.

\begin{tabular}{|c|c|c|c|c|}
\hline Welfare indicator & Crop Farming & Tourism-related & $\begin{array}{c}\text { Tilapia } \\
\text { Aquaculture }\end{array}$ & $\begin{array}{l}\text { Other income } \\
\text { sources }\end{array}$ \\
\hline Average annual income (PhP/US\$) & $108,086 / 2131$ & $164,461 / 3243$ & $132,800 / 2619$ & $211,867 / 4178$ \\
\hline $\begin{array}{l}\text { Proportion of households whose income is } \\
\text { below poverty threshold }\end{array}$ & $77.83 \%$ & $51.43 \%$ & $62.50 \%$ & $44.78 \%$ \\
\hline $\begin{array}{l}\text { Proportion of households whose income is } \\
\text { below food threshold }\end{array}$ & $63.21 \%$ & $34.29 \%$ & $50.00 \%$ & $46.22 \%$ \\
\hline Proportion of households which have missed meals & $53.77 \%$ & $42.86 \%$ & $30.00 \%$ & $36.32 \%$ \\
\hline Average happiness score & 6.75 & 6.94 & 7.70 & 6.99 \\
\hline
\end{tabular}

\section{Financing and Marketing Constraints}

Interviews and focus group discussions (FGD) with farmers in Lakes Sebu that allowed more in-depth investigation on their conditions revealed farming households' vulnerabilities arising from limited financing and marketing options.

Although most of the FGD participants claimed that they own the land that they cultivate, all of them have no savings to fund their farming livelihood activities and hence, depend on financiers to cover farming costs from seed sowing to marketing. Some acquire cash financing from informal loan sharks at interest rates of $5 \%-10 \%$ per month (equivalent to an annual interest rate of $60 \%-$ $120 \%)$. But most farmers enter into a financing contract with agricultural traders who normally provide them with all farm inputs-seedlings, fertilizers, herbicides, and pesticides. The prices of the farm inputs are set in the contract at levels that are much higher than market prices. All contract prices are fixed such that even if the market price of a farm input falls, the price set in the contract is not changed. For example, a bag of fertilizer that costs PHP950 in the market is provided by the financier to the farmer at PHP1,500. There have been instances that the market price of fertilizer falls to as low as PPH650, but the PHP1,500 price set in the contract is not amended. In most cases, the agricultural traders who provide the farm inputs are also the buyers of the crops. While they set very high input prices in the contract, they buy crop harvests at very low prices. Further, they charge transportation costs of PHP1.80 for every kilogram of the crop, leaving the farmers with very little net income for their harvests.

It is very difficult for the subsistence Lake Sebu farmers to bring their produce and sell directly to the market to get a fairer price for their produce due to the absence of concrete farm to market roads. Roads are hardly passable during rainy days. World Bank (2020) [2] notes that transportation costs can rise by an additional $71 \%$ during the rainy season. Produce from upland farms has to be transported using horses or motorcycles to lowland areas. Apart from higher transportation costs, the shortage of drying facilities and transport difficulties 
result in high spoilage and further losses to the farmers during the rainy season.

\section{Government Support and Intervention Programs}

In the Philippines, the Department of Agriculture, in partnership with the local government units, is mandated to provide the support services necessary to make agriculture and agriculture-based enterprises profitable. Lake Sebu's Municipal Agriculturist claimed that the Department of Agriculture provides farm inputs (e.g.: rice/corn seedlings, fertilizer), farm equipment (e.g.: thresher, corn

sheller), farming seminars and trainings, and livelihood programs. These interventions are provided through farmers' organizations. Free seedlings and fertilizers from the government are distributed by recognized farm organizations to their members. Farm equipment and implements such as thresher and corn sheller, on the other hand, are given to the farm association and thus become communal properties of the members who are assigned schedules for use. Hence, only farmers who are members of a recognized farmers' organization are able to avail of the government programs and support services. There are many cases where farmers can not comply with the responsibilities and deliverables required of members and beneficiaries of government programs and assistance. For example, farmers in far-flung, upland areas find it so hard to attend regular meetings and to comply with tedious reporting requirements and other protocols. Some farmers feel inadequate and unqualified to become members of organizations. Hence, not so many farmers are able to benefit from the government's agricultural assistance program.

Further, there are issues about the quality of farm inputs provided by the government. FGD participants revealed that corn seedlings from the government are not growing either because of poor quality and/or they are not suited for the soil chemistry in Lake Sebu. The Municipal Agriculturist did not deny this claim of the farmers, but they argued that they have no control over the quality of the farm inputs as their office only depends on the provisions of the Department of Agriculture. The poor performance record of the farm inputs is another reason why many farmers in Lake Sebu are forgoing government assistance, particularly the free farm inputs program.

In terms of infrastructure, five projects-three farm-to-market roads and two bridges-are soon to be completed in the Municipality as part of the Department of Agriculture's Mindanao Sustainable Agrarian and Agriculture Development Program. These projects are expected to make the transport of farms products to market centers fast, safe and convenient, thereby benefiting primarily the agricultural barangays (Business World, 2020 [11]).

\section{Conclusion and Recommendations}

A look into the plight of farmers in the Municipality of Lake Sebu mirrors the conditions of low-productivity subsistence agriculture that is still prevalent in 
predominantly Muslim and indigenous people-inhabited areas of Mindanao in the southern Philippines (Muyrong and Dizon, 2020 [12]) due to the twin constraints on sourcing and financing of farm inputs and on marketing of produce in the absence of a link with high-value markets (Habito and Briones, 2005 [13]). These twin constraints maintain the dominating presence of the middlemen that set high input prices and low farm-gate output prices.

Public programs and policy reforms are necessary to address these twin constraints to agricultural development and poverty alleviation in Lake Sebu. Four crucial reforms are discussed below:

First is a comprehensive logistics program that will expand farm-to-market road networks up to the far-flung and upland farms in Barangay Ned. The lack of roads necessitate the use of horses and motorcycles to bring produce from the uplands to the lowlands and the lack of internal connectivity (that will allow a smooth loading and unloading of the produce between different forms and stages in the delivery process) result in double handling, food wastage, and failure of product consolidation, leading to higher per unit transport and handling costs. Because of these complicated and high logistics costs, Lake Sebu farmers prefer that traders pick up their produce and do not pursue higher prices by delivering their products directly to buyers. The three roads and two bridges project must just be the start of a complete farm-to-market infrastructure program.

Second is a broad facilitation program for linking farmers and markets. Small farmers struggle to access inputs and output markets. Farm produce buyers (such as agribusiness and wholesalers), on the other hand, are having difficulty getting the quantity and quality of the produce they need on a consistent and timely basis. Government assistance in overcoming this market failure by bringing together buyers and producers is needed. Government must also provide support for the preparation and implementation of profitable business plans. This response can include investments and technical assistance for the formation of producers' organizations or groups and for strengthening the organizational and entrepreneurial capacity of producer organizations, if they already exist. This type of market-linking facilitation program is in line with the productive alliance model that is already tried in comparative developing countries such Vietnam, Bolivia, Brazil and Colombia (WB, 2020), and even in the Philippines as part of the Philippine Rural Development Project (PRDP). PRDP aims to develop the rural agricultural sector by providing key support services that strengthen market access and farm-to-market linkages, improving the entrepreneurial capacities of producer groups, and opening up opportunities in production, postharvest processing, product value addition, and marketing. PRDP relies on a science-based planning framework and synergies among national government agencies, provincial and municipal local governments, and the private sector, to support investments that promote sustainable and equitable growth in productivity and income for farmers (WB, 2020). There have been some initiatives from private individuals in this area. One migrant family from a neighboring munici- 
pality has given training to Lake Sebu farmers on organic banana growing, and has gathered the produce of these farmers for export sales. This is the kind of private initiative that national and local government agencies can support as part of their rural agricultural development program.

Third, farming subsidies in the form of cash transfers may also be tried in lieu of direct provision of farm inputs (seeds, fertilizers, chemicals). As part of the agricultural reform programs in countries such as Mexico, Turkey and the US, direct support in the form of cash transfers are given to farmers who are struggling to earn a livelihood due to crop production and market engagement constraints, instead of direct provision of farm inputs by the government. Cash payments go directly to farmers, usually on a per hectare basis, and the amount of the payment is not dependent on production or input use, and hence, it has been referred to as "decoupled payments". This system gives the farmers more freedom in the use of farming techniques of their choice and more incentives for private sector development in upstream (inputs and agricultural services) and downstream (processing, marketing) markets, thereby helping farmers connect to value chains. Further, support can be made conditional on actions that generate positive externalities. For example, cash transfers or rewards can be given to farmers who practice farming techniques that are not destructive to the environment. If this is the case, the cash transfers to the farmers take the form of the Payment for Environmental Services scheme. In Lake Sebu, the municipal government already has a program of giving "cash prizes" as incentives for farmers practicing sustainable agriculture, such as organic farming or minimal use of chemical fertilizers and pesticides. Agricultural wastewater pollutes surrounding lakes and streams that also provide major livelihood activities for residents-tourism and aquaculture. Such project can be extended to all farming areas, and not limited to lake barangays.

Last is a well-designed program to promote crop diversification. Lake Sebu's topography, climate, and fertile soil are suited for different crops. FGD and survey results reveal that there are a host of other crops that can be grown in Lake Sebu and that are substantially more profitable than corn. Lake Sebu farmers, most of them the indigenous residents, are just reluctant to venture into these other crops due to insufficient knowledge and skills. This calls for well-designed training programs to introduce and illustrate new agricultural crops and techniques. With the dismantling of the traditional reliance on corn middlemen that can ensue from the first three program recommendations, crop diversification may also be realized. But technical training programs will be a necessary component of the entire reform agenda. The research finds that it is the migrant residents who have modern knowledge in modern agriculture that are venturing into the farming and processing of other crops such as turmeric tea, stevia sugar, honey, cocoa, dried blue butterfly pea, and other organic products. Training programs have to cater to the majority of farmers who are the indigenous residents of the Municipality. 


\section{Acknowledgements}

This study was undertaken with a research grant from the Philippine Commission on Higher Education. Research assistance of Ms. Marilyn Palanca, Mr. Gerome Vedeja and Ms. Kristine Alorro, and the enthusiastic participation of KII, FGD and survey respondents are gratefully acknowledged.

\section{Conflicts of Interest}

The authors declare no conflicts of interest regarding the publication of this paper.

\section{References}

[1] Imai, K., Gaiha, R. and Thapa, G. (2011) Role of Agriculture in Achieving MDG1 in Asia and the Pacific Region.

https://econpapers.repec.org/paper/kobdpaper/dp2011-01.htm

[2] World Bank (WB) (2020) Transforming Philippine Agriculture: During Covid-19 and Beyond.

http://documents1.worldbank.org/curated/en/614671593417939107/pdf/Transformi ng-Philippine-Agriculture-During-COVID-19-and-Beyond.pdf

[3] Brown, E., Ebora, R. and Decena, F.L. (2018) The Current State, Challenges and Plans for Philippine Agriculture. FFTC Agricultural Policy Article. https://ap.fftc.org.tw/

[4] Lake Sebu Municipal Planning and Development Office (LSMPDO) (2015) Lake Sebu Comprehensive Land Use Plan 2014-2023. Lake Sebu Municipal Government, South Cotabato, 237 p.

[5] Lake Sebu Municipal Planning and Development Office (LSMPDO) (2016) Lake Sebu Socio-economic and Ecological Profile. Lake Sebu Municipal Government, South Cotabato, $72 \mathrm{p}$.

[6] Office of the Municipal Agriculturist (OMA) (2019) Unpublished Office Records. Municipal Government of Lake Sebu, Lake Sebu.

[7] Cantril, H. (1965) The Pattern of Human Concerns. Rutgers University Press, New Brunswick.

[8] Philippine Statistics Authority (PSA) (2010) Updated Production Costs and Returns of Selected Agricultural Commodities-Palay and Corn.

[9] Philippine Statistics Authority (PSA) (2015) Updated Production Costs and Returns of Selected Agricultural Commodities-Palay and Corn.

[10] Philippine Statistics Authority (PSA) (2018) Updated Production Costs and Returns of Selected Agricultural Commodities-Palay and Corn.

[11] Business World (2020) 3 Farm-to-Market Roads Completed in Lake Sebu. https://www.bworldonline.com/3-farm-to-market-roads-completed-in-lake-sebu/

[12] Muyrong, M.S. and Dizon, R.J.R. (2020) Then and Now: A Profile of the Agrarian Environment in Mindanao.

[13] Habito, C. and Briones, R. (2005) Philippine Agriculture over the Years: Performance, Policies, and Pitfalls.

http://siteresources.worldbank.org/INTPHILIPPINES/Resources/Habito-word.pdf. 